\title{
УДК 347.4
}

DOI https://doi.org/10.32847//n.2019.9.05

\author{
Гуйван П.Д. \\ к.ю.н., професор, \\ заслужений юрист Украӥни \\ Полтавський інститут бізнесу
}

\section{УКРАЇНСЬКЕ ПРАВОЗАСТОСУВАННЯ ЄВРОПЕЙСЬКИХ ПРИНЦИПІВ ВІЛЬНОГО ДОСТУПУ ДО ІНФОРМАЦІЇ В РАЗІ ОРГАНІЗАЦІЇ СУДІВНИЦТВА}

Постановка проблеми. Право особи на вільний доступ до інформації є елементом свободи слова як визначального та основоположного принципу демократії, гуманності та справедливості. Ступінь розвитку цього права характеризує ступінь прогресу самого суспільства, рівень особистої свободи особи, який реально забезпечується державою [1, с. 50]. Це право включає такі конкретні повноваження, як необхідність знати про створення певних інформаційних ресурсів, які мають відношення до сфери суспільного чи особистого життя особи, можливість запитувати та отримувати публічно значиму чи особисту інформацію від уповноважених на розпорядження нею суб'єктів, вільно поширювати iї та вимагати у встановлених законом випадках дотримувати конфіденційності.

Водночас інформаційні права особи не можуть бути безмежними. При їхній реалізації застосовуються обмеження, в загальному вигляді передбачені в ст. 13 Цивільного кодексу України: право не може використовуватися на шкоду інтересам інших осіб, державній безпеці, довкіллю, всупереч моральним засадам суспільства. Відповідно до правил ст. 6 ЗУ «Про доступ до публічної інформації» при виявленні загрози такого рівня доступ до інформації може бути обмеженим. Але подібні обмеження застосовуються виключно тоді, коли існує навіть не одна, а реальна сукупність таких вимог: 1) виключно в інтересах національної безпеки, територіальної цілісності або громадського порядку з метою запобігання заворушенням чи злочинам, для охорони здоров'я населення, для захисту репутації або прав інших людей, для запобігання розголошенню інформації, одержаної конфіденційно, або для підтримання авторитету і неупередженості правосуддя; 2) розголошення інформації може завдати істотної шкоди цим інтересам; 3 ) шкода від оприлюднення такої інформації переважає суспільний інтерес в її отриманні.

Як бачимо, існує презумпція відкритості публічної інформації, і в цьому плані держава в особі своїх органів управління має здійснювати певний комплекс заходів, аби забезпечити громадянам доступ до інформаціï, яка міститься в офіційних документах. При цьому факт належності відомостей до категорії закритих чи обмежених у доступі має бути доведеним саме суб'єктом владних повноважень, який є розпорядником відповідної інформації. Разом із тим зазначені чіткі приписи чинного національного інформаційного законодавства, на жаль, не завжди знаходять застосування у вітчизняній правозастосовній практиці. Насправді, публічні органи влади часто порушують права громадян на отримання суспільно значимих відомостей. Відмови чи зволікання в доступі відбувається під різними приводами, при цьому владний суб'єкт такі рішення про відмову ухвалює на власний розсуд, ніяк не мотивуючи або роблячи неналежну мотивацію. Типовою є практика надання замість запитуваної іншої, зазвичай загальної інформації, яка не дає змогу задовольнити суспільні чи особисті потреби запитувача. При цьому спостеріга- 


\section{ЦИВІЛЬНЕ ПРАВО І ЦИВІЛЬНИЙ ПРОЦЕС; СІМЕЙНЕ ПРАВО; МІЖНАРОДНЕ ПРИВАТНЕ ПРАВО}

ється фактична віддаленість змісту мотивації від обставин справи, встановлених фактів та приписів правових норм.

Огляд останніх досліджень і пуб̆лікацій. Проблематиці правової організації вільного доступу зацікавлених осіб до інформації, яка має суспільний інтерес, присвячені наукові праці таких правників, як О. Бандурка, Є. Захарова, Н. Гудима, М. Поліковський, О. Пушкар, Г. Почепцов, Т. Гуржій, В. Коваль, Т. Шевченко, М. Демкова та інші. Однак, попри загалом значну увагу вчених до питань юридичного оформлення можливості конкретної особи щодо доступу до публічної інформації, не отримали детального правового дослідження важливі аспекти діяльності суб'єктів владних повноважень стосовно дотримання визначених законом засад обмеження доступу громадян до вказаних даних. Отже, потребують подальшого розвитку концептуальні напрацювання критеріїв належності обгрунтування мотивації прийнятого рішення, 3 урахуванням обгрунтованості врахування чи відхилення тих чи інших фактичних обставин та аргументів. Не напрацьовано єдиного правового підходу до визначення обов'язків органів влади щодо обмеження невиправданої конфіденційності, встановлення переліку публічних соціально важливих відомостей, які є необхідними для особи і дають змогу належно задовольнити їі публічний інтерес.

Формулювання завдання дослідження. 3 урахуванням цього метою роботи є вивчення національних правових актів, що гарантують вільний доступ до інформації, та здійснення аналізу його застосування з визначенням вад у національній правовій системі.

Виклад основного матеріалу. Рішення адміністративного органу, який має функції утримувача i розпорядника інформації, що становить публічний інтерес, про фактичне обмеження доступу до неї має щоразу грунтуватися на вказаних у законі обставинах фактичного порядку, а саме наявності в разі оприлюднення або надання широкого доступу загрози охоронюваним інтересам, що супроводжується реальним завданням істотної шкоди цим інтересам, а також того факту, що розмір такої шкоди не просто спів мірний, але й переважає суспільний інтерес в отриманні публічних відомостей. Лише за наявності повного складу обставин із зазначеного переліку виникає юридична можливість застосування розпорядниками певних обмежень щодо подібної інформації. При цьому, коли інформація не належить до такої, що обмежена, вона має надаватися будь-якому визначеному ст. 13 Закону України «Про доступ до публічної інформації» запитувачу, незалежно від способу подання запиту - в усній, письмовій чи іншій формі на його вибір.

Це означає, що розпорядник мусить чітко обгрунтувати та мотивувати свою відмову в доступі. Згідно з практикою Європейського суду з прав людини, однією з головних ознак належного правозастосування адміністративного органу є гарантування особі високого рівня обгрунтованості та мотивованості рішень, які виносяться суб'єктами владних повноважень. Від обгрунтованості правового документа, що виноситься, значною мірою залежить якість актів правової системи як складової частини ii юридичної певності. Важливо, що висновки, яких дійшов владний орган, мають базуватися на встановлених фактах, і це становить квінтесенцію правового обгрунтування рішення, а мотивованість - це наявність у самому документі посилання на обставини, встановлені на підставі цих фактів, та їхню оцінку, на тлумачення застосованої правової норми при кваліфікації правовідношення [2, с. 124]. Інакше кажучи, правовий вчинок $є$ обгрунтованим, коли його висновки грунтуються на об'єктивній реальності, встановленій при вивченні конкретних обставин справи, в той час, як мотивованість акта виявляється в юридичній аргументації, переконливості, що досягнуто шляхом викладення фактичних і правових підстав прийнятого рішення [3, с. 269]. Водночас в Україні постійно спостерігаються приклади, коли 


\section{ЦИВІЛЬНЕ ПРАВО І ЦИВІЛЬНИЙ ПРОЦЕС; СІМЕЙНЕ ПРАВО; МІЖНАРОДНЕ ПРИВАТНЕ ПРАВО}

розпорядник самочинно кваліфікує публічні відомості в якості обмежених у доступі. Це часто робиться без будь-якого обгрунтування та мотивації, керуючись лише власним авторитетом. На жаль, і судова система України переважно зважає також на авторитет органу влади, а не на закон, який, як вже вказувалося, встановлює інші пріоритети. Втім, іноді має місце певне намагання обгрунтувати подібну відмову особі в доступі до публічної інформації. При цьому найширше використовується така аргументація: поширення відомостей може зашкодити приватності певних осіб, бо містить інформацію, що $є$ персональними даними; запитувані відомості включені до переліку обмежених, затверджених відповідним суб'єктом владних повноважень. Розглянемо зазначені аспекти питання більш детально.

Повторимо, будь-яка інформація, що має суспільний інтерес, $є$ такою, оборот якої регулюється Законом «Про доступ до публічної інформації». А це означає, що іноді виникає правова колізія між приватноправовим інтересом стосовно недоторканості персональних даних про особу i публічно-правовим щодо вільного доступу до інформації. Зазвичай у цьому протистоянні перевага надається приватному інтересу конкретної людини, і це правильно. Адже право особи на недоторканість особистої інформації $є$ найвищою цінністю в сучасному демократичному суспільстві навіть попри окремі перешкоди суспільному благу. Достатньо згадати резонансну справу Центру «Миротворець» [4] та судові рішення в кількох американських юрисдикціях щодо заборони використання технічних засобів розпізнавання облич [5]. Але то стосується лише інформації, що має відношення до пересічних громадян. Інша річ - публічні персони. Відомості про їхню діяльність, навіть приватне життя, включаючи ті, що становлять персональні дані, мають іноді значний публічний інтерес. І ось у цьому разі владний суб'єкт, який має в розпорядженні відповідну інформацію, мусить не лише констатувати факт наявності персональних даних, але ще і здійснити обгрунтоване дослідження та зробити мотивований висновок про неможливість оприлюднення цих даних.

Закон чітко встановлює, як слід діяти в подібній ситуації, хоча мусимо зазначити, зо владні структури практично цього ніколи не роблять. Між тим, нормативний акт - Закон України «Про доступ до публічної інформації» стверджує, що навіть, якщо цю інформацію кваліфікувати як персональні дані, це далебі не виключає можливість ознайомлення 3 інформацією про інших осіб, якщо це необхідно для реалізації публічних інформаційних прав та законних інтересів. Визначено і певну процедуру, в межах якої відбувається дослідження та прийняття рішення 3 такого питання. Це так званий трискладовий тест. Правило про його проведення вимагає не лише зазначення правових підстав для обмеження інформації у доступі, про які зазначалося вище, а й аргументовано обгрунтувати і таким чином доказати їі. 3 відмови у доступі до публічної інформації має вбачатися: 1) якому 3 перелічених у п. 1 ч. 2 ст. 6 Закону «Про доступ до публічної інформації» інтересів відповідає обмеження, а також чому обмеження доступу відповідає зазначеному інтересу; 2) в чому конкретно полягає шкода правомірному інтересу; яким є причинно-наслідковий зв'язок між наданням доступу та можливим настанням шкоди; чому ця шкода $є$ істотною; яка ймовірність настання шкоди внаслідок надання доступу до інформації (п. 2 ч. 2 ст. 6 Закону); 3) чому шкода від надання інформації переважає суспільний інтерес в їі отриманні (п. 3 ч. 2 ст. 6). Відсутність висновку розпорядника інформації щодо наявності хоча б однієї зі згаданих трьох підстав «трискладового тесту» означає, що законних підстав для обмеження доступу до інформації немає, а відмова у доступі до публічної інформації $є$ необгрунтованою. Тому якщо під час розгляду справи в суді буде з'ясовано, що, відмовляючи в задоволенні запиту на інформацію розпорядник 


\section{ЦИВІЛЬНЕ ПРАВО І ЦИВІЛЬНИЙ ПРОЦЕС; СІМЕЙНЕ ПРАВО; МІЖНАРОДНЕ ПРИВАТНЕ ПРАВО}

не застосовував «трискладового тесту» або застосував його лише формально, то це $\epsilon$ підставою для визнання такої відмови розпорядника протиправною [6]. Отже, вказане тестування обов'язково застосовується в кожному випадку, коли конкретній інформації надається статус «для службового користування».

Інша ситуація, коли посадовці відмовляють у вільному доступі до інформації у зв'язку з їі віднесенням своїм адміністративним актом до категорії обмеженої, теж не менш показова. Дійсно, закон передбачає можливість створення органами державної влади переліку відомостей, що становлять службову інформацію. Але при цьому варто зважати, що перелік, у разі затвердження, має складатися з абстрактних категорій інформації, яка може бути зарахована до службової, безвідносно до конкретної інформації (конкретного документа). Тобто, по суті, йдеться не про конкретні документи, а про перелік категорій відомостей, які можуть бути зараховані до службової інформації. Перелік слугує для розпорядників та запитувачів тільки орієнтиром щодо інформації, доступ до якої може бути обмежено, у разі, якщо застосування «трискладового тесту» в кожному конкретному випадку надасть підстави для ï обмеження. При цьому важливо, що до переліку можуть бути включені лише відомості, що становлять службову інформацію, відповідно до ч. 1 ст. 9 Закону № 2939-VI.

Своєю чергою, за приписом цієї норми до службової може належати тільки інформація, що міститься в документах суб'єктів владних повноважень, які становлять внутрівідомчу службову кореспонденцію, доповідні записки, рекомендації, якщо вони пов'язані з розробкою напряму діяльності установи або здійсненням контрольних, наглядових функцій органами державної влади, процесом прийняття рішень і передують публічному обговоренню та/або прийняттю рішень, а також дані, зібрані в процесі оперативно-розшукової, контррозвідувальної діяльності, у сфері оборони країни, яку не зараховано до дер- жавної таємниці. Якщо ж відомості не підпадають під встановлені законом виключні ознаки, включення їх до переліку даних, що $\epsilon$ обмеженими в доступі, є протизаконним.

Зазначені нормативні положення можемо проілюструвати на прикладі судового рішення у справі № $800 / 333 / 17$, яка розглядалася Верховним Судом у 2018 р. [7]. У цій справі позивач оскаржував відмову Вищої кваліфікаційної комісії суддів України надати йому доступ до інформації про складання ним іспиту, зокрема, в частині обгрунтованості та мотивованості отриманої конкурсантом оцінки. Відповідач відмовився це зробити, аргументуючи відмову якраз включенням відомостей про результати оцінювання конкурсантів Комісією до Переліку службової інформації, затвердженого наказом ВККСУ. Тобто у суді, передусім, мало досліджуватися питання обгрунтованості внесення вказаних відомостей до переліку з урахуванням означених нормативних приписів. Якщо їх уважно дослідити та зіставити 3 матеріалами справи, неважко було помітити, що інформація про себе, запитувана позивачем, не належить до внутрівідомчої службової кореспонденції, доповідних записок, рекомендацій, а також до такої, що зібрана у процесі оперативно-розшукової, контррозвідувальної діяльності. Тож, зарахування відповідачем запитуваних відомостей до службової інформації є неправомірним. Отже, акт відповідача - наказ № 24 Вищої кваліфікаційної комісії суддів України від 5 квітня 2017 р. не є законним i не може застосовуватися адміністративним судом 3 огляду на припис ч. 4 ст. 9 КАСУ як такий, що відверто суперечить акту вищої сили - Закону України «Про доступ до публічної інформації». Однак Верховний Суд чомусь цього не помітив.

Також суд відверто проігнорував такий вагомий аргумент, що матеріально-правовий нормативний акт - наказ, яким встановлювався перелік відомостей, що зараховані до службової інформації, не був чинним на час спірних відносин, хоча це питання ретельно 


\section{ЦИВІЛЬНЕ ПРАВО І ЦИВІЛЬНИЙ ПРОЦЕС; СІМЕЙНЕ ПРАВО; МІЖНАРОДНЕ ПРИВАТНЕ ПРАВО}

і тривало обговорювалося в судовому засіданні. Згідно з Конституцією України та законами України, нормативні акти не можуть використовуватися, якщо вони не доведені у належний спосіб до осіб, яких стосуються. Ст. 15 Закону України «Про доступ до публічної інформації» вказує, що розпорядники інформації зобов'язані оприлюднювати нормативно-правові акти, акти індивідуальної дії (крім внутрішньоорганізаційних), прийняті розпорядником, проекти рішень, що підлягають обговоренню, інформацію про нормативно-правові засади діяльності. Проекти нормативно-правових актів, рішень органів місцевого самоврядування, розроблені відповідними розпорядниками, оприлюднюються ними не пізніш як за 20 робочих днів до дати їх розгляду з метою прийняття.

Між тим, як було встановлено у засіданні, наказ № 24 від 5 квітня 2017 р. був оприлюднений 28 квітня 2017 р. Спірні ж відносини де-факто відбувалися 35 по 8 квітня 2017 р. Тож застосування цього нормативного акта до них «заднім числом» не $є$ законним. 3 цього приводу вищі судові органи держави неодноразово давали певні рекомендаціiі. Так, у п. 7 постанови Пленуму Верховного Суду України від 1 листопада 1996 р. № 9 «Про застосування Конституції України при здійсненні правосуддя» було запропоновано звернути увагу судів на те, що згідно 3 ч. 2 ст. 57 Конституції $є$ нечинними, а отже, не можуть застосовуватись ті закони та інші нормативно-правові акти, що визначають права і обов'язки громадян, які не доведені до відома населення у встановленому законом порядку. Це означає, що судове рішення не може грунтуватись на неоприлюднених нормативно-правових актах такого змісту.

Як вказує ст. 58 Конституція України, жоден нормативний правовий акт не має зворотної дії, крім випадків, коли він пом'якшує чи скасовує відповідальність особи. Ст. 8 КАСУ вказує, що при розгляді справ адміністративний суд застосовує принцип верховенства права 3 урахуванням судової практики Свропейського Суду з прав людини. Крім того, Європейський суд із прав людини постулює правило про незворотність дії правових актів як один із необхідних елементів принципу правової визначеності як елементу права особи на справедливий суд, встановленого у §6 Конвенції про захист прав людини і основоположних свобод [8].

Саме подібними правовими підходами мусив керуватися і Верховний Суд при розгляді коментованої справи. Але, як ні прикро, маємо беззаперечний факт: всі правові рішення вищих правозастосовних інституцій в Україні застосовуються лише в тих випадках, коли то стосується пересічних громадян. Коли ж йдеться про «своїх», а тим більше про орган державного контролю за діяльністю судів, справедливість, неупередженість судочинства відразу втрачаються як притаманні явища. На перший план відразу виходять корпоративність, особистий інтерес, корупційні зв'язки. Такий ось результат «судової реформи». Як сьогодні переконливо продемонстрував розгляд подібних справ у Верховному Суді, цей орган не є незалежним, як то передбачено законом та не відповідає суспільним прагненням національної громади. Важливо зазначити, що це помітила і нова українська влада. Зокрема, в першому читанні Верховна Рада затвердила законопроект № 1008, в якому передбачається переатестація та серйозні зміни у складі Верховного Суду, а головне - запровадження нових більш демократичних та прозорих механізмів створення та діяльності державного органу, що здійснює формування національного судівництва, в тому числі серйозні кадрові зміни ВККСУ та принципів організації їі діяльності, включаючи чесні та прозорі процедури в інформаційній сфері.

Власне питання щодо законності обмежень доступу особи до публічної інформації є дуже важливим, і від його правильного вирішення значною мірою залежить подальший рух України до європейської демократії. Будь-яке обмеження права обов'язково 


\section{ЦИВІЛЬНЕ ПРАВО І ЦИВІЛЬНИЙ ПРОЦЕС; СІМЕЙНЕ ПРАВО; МІЖНАРОДНЕ ПРИВАТНЕ ПРАВО}

має бути спрямовано на захист законних інтересів. Такі цілі обмеження доступу до інформації, як виняткова ситуація, яка може поставити державні органи або їхніх посадових осіб у невигідне становище, не можна ні приховано, ні безпосередньо класти в основу законного обмеження права на інформацію. Доводи обгрунтування обмеження мали відповідати поставленим цілям. Але, якщо мету можна захистити іншим способом, не пов'язаним 3 обмеженням права, перевагу необхідно віддати останньому. Специфіка інформації про діяльність державних органів i органів місцевого самоврядування полягає в тому, що ці органи є власниками найбільшого обсягу суспільно значущої інформації, у яку, як правило, входять інші категорії інформації, що викликає підвищений суспільний інтерес через їхній вплив на всі сфери людської діяльності. Право на доступ до інформації є ключовим елементом громадського контролю [9, с. 89].

З викладеного можемо дійти певних висновків. Належний та пропорційний розвиток суспільства постійно потребує відповідного отримання, аналізу та поширення достовірної інформації. 3 часом відбувається деталізація, диференціація і спеціалізація інформації, яка може становити суспільний інтерес і має бути доступна всім членам суспільства без істотних формальних перешкод. Доступ до інформації, яка становить публічний інтерес, є одним 3 основних інструментів підвищення відкритості влади. Отримання вказаних відомостей істотно впливає на очікуваність та визначеність правового статусу особи, надає їй змогу планувати зміни у своєму особистому житті та житті суспільства. Отже, необхідно, щоб в соціумі були встановлені чіткі та зрозумілі правила поведінки у даній сфері.

Найбільш актуальними питаннями, які потребують нагального та серйозного втручання, аби досягти рівня основних демократій у галузі доступу до інформації, це численні відписки розпорядників публічної інформації на отримані запити, приховування інформації органами влади, надання неповної інформації або відмова надати копії запитаних документів, порушення термінів надання відповідей на запити. Посадові особи суб'єктів владних повноважень, як показує практика, часто посилаються на законодавчі акти, які на відповідають критерію визначеності їх застосування, але дозволяють чиновникам із різних причин відмовляти в наданні інформації за запитом. Зрештою, важливим дисциплінуючим фактором має стати запровадження реальної відповідальності чиновників за допущені ними порушення при реалізації заявниками своїх прав на отримання інформації.

\section{Анотація}

Стаття присвячена правовому вивченню актуального питання стосовно ролі та значення відкритої інформаційної політики при реалізації національними владними установами своїх повноважень. У цьому сенсі досліджено нормативне регулювання та правозастосовну практику в царині здійснення права особи на вільний доступ до інформації, яке є елементом свободи слова як визначального та основоположного принципу демократії, гуманності та справедливості. Водночас у роботі зазначається, що інформаційні права особи не можуть бути безмежними. Аналізуються правові принципи і механізми обмежень цього права, які можуть застосовуватися виключно з легітимною метою: лише для захисту охоронюваних законом суспільних та особистих інтересів із метою запобігання завдання їм істотної шкоди, коли їі розмір переважає суспільний інтерес в отриманні публічної інформації.

Констатовано, що в нашій державі таких принципів дотримуються далеко не завжди. Органи влади часто порушують права громадян на отримання суспільно значимих відомостей. Відмова чи зволікання а доступі відбувається під різними приводами, при цьому владний суб'єкт такі рішення про відмову ухвалює на власний розсуд, ніяк не мотивуючи або роблячи нена- 


\section{ЦИВІЛЬНЕ ПРАВО І ЦИВІЛЬНИЙ ПРОЦЕС; СІМЕЙНЕ ПРАВО; МІЖНАРОДНЕ ПРИВАТНЕ ПРАВО}

лежну мотивацію. Типовою є практика надання замість запитуваної іншої, зазвичай загальної інформації, яка не дає змогу задовольнити суспільні чи особисті потреби запитувача. На конкретних прикладах із судової практики показано відірваність практичного правозастосування від загальноприйнятих моделей справедливого інформаційного обороту соціально значимих відомостей. Наочно це проявляється при щойно проведеному реформуванні вищого суддівського корпусу держави. Мають місце необгрунтовані та протиправні відмови органу держави, покликаного здійснювати добір суддів, у доступі громадян до публічної інформації з посиланням на те, що певні дані включені до переліку обмеженої інформації. Хоча, насправді, то не відповідає встановленим законам критеріям, або перелік, відповідно, не має застосовуватися, бо не був у встановленому порядку оприлюдненим на час спірних відносин. У роботі зазначається, що українська судова система, всупереч закону, заохочує подібні зловживання, надаючи неправомірний пріоритет інтересам суб'єктів владних повноважень.

Надані конкретні правові рекомендації щодо виправлення становища у цій сфері та підтримання позиції нової влади стосовно запровадження нових більш демократичних та прозорих механізмів діяльності розпорядників інформації.

Ключові слова: публічні відомості, обмеження доступу, інформаційний запит.

\section{Guyvan P.D. Ukrainian enforcement of European principles of free access to information in the organization of judiciary \\ Summary}

The article is devoted to the legal study of the topical issue regarding the role and importance of open information policy in the exercise of national powers by national authorities. In this sense, the regulation and enforcement practices in the field of exercising a person's right to free access to information, which is an element of freedom of speech as a determining and fundamental principle of democracy, humanity and justice, are explored. At the same time, the paper notes that information rights of a person cannot be infinite. The legal principles and mechanisms of restriction of this right, which can be used solely for legitimate purpose, are analyzed: only for the protection of public and private interests protected by the law in order to prevent them from doing substantial harm when its size outweighs the public interest in obtaining public information.

It is stated that in our country such principles are not always observed. Authorities often violate citizens' rights to obtain publicly available information. Denials or delays in access are subject to various pretexts, with the ruling entity making such denial decisions in its sole discretion, without motivating or inappropriately motivating. It is common practice to provide, instead of the requested other, generally general information that does not satisfy the public or personal needs of the requester. Case-law examples show the detachment of practical enforcement from generally accepted models of fair information circulation of socially relevant information. This is evident in the reform of the state's highest judicial corps that has just been carried out. There are unjustified and unlawful refusals by a body of the state called upon to select judges in the access of citizens to public information, with reference to the fact that certain data are included in the list of restricted information. Although, in fact, it does not meet the statutory criteria, or the list should not be applied accordingly, because it was not promulgated at the time of the disputed relationship. The paper notes that, contrary to the law, the Ukrainian judicial system encourages such abuses, giving undue priority to the interests of the authorities.

Specific legal recommendations have been provided to remedy the situation in the field and to support the position of the new authorities regarding the introduction of new, more democratic and transparent mechanisms for the activity of information stewards.

Key words: public information, access restrictions, information request. 


\section{ЦИВІЛЬНЕ ПРАВО І ЦИВІЛЬНИЙ ПРОЦЕС; СІМЕЙНЕ ПРАВО; МІЖНАРОДНЕ ПРИВАТНЕ ПРАВО}

\section{Список використаних джерел:}

1. Цибульська А.В. Право на доступ до інформації в Україні: конституційно-правовий аспект. Вісник Дніпропетровського університету імені Альфреда Нобеля. Серія «Юридичні науки». 2013. № 2 (5). С. 49-54.

2. Викут М.А. Законность и обоснованность актов социалистического правосудия как главное условие выполнения задач гражданского судопроизводства. Цивилистические проблемы правового статуса личности в сочиилистическом обществе. Саратов : Изд-во Сарат. ун-та, 1982. C. $122-124$.

3. Вопленко Н.Н. Теоретические проблемы режима законности в применении норм социалистич. Права : дис. ... д-ра юрид. наук. Волгоград, 1983. 408 с.

4. Тополевський Р. Право на приватність. URL: https://helsinki.org.ua/pravo-na-pryvatnist-r-topolevskyj/

5. Лі Д. У США вперше заборонили технологію розпізнавання обличчя. Чому? URL: https://www.bbc.com/ukrainian/news-48278205

6. Про практику застосування адміністративними судами законодавства про доступ до публічної інформації : Постанова Пленуму Вищого адміністративного суду України № 10 від 29.09.2016. URL: https://zakon.rada.gov.ua/laws/show/v0010760-16

7. Справа № 800/333/17. Архів Касаційного адміністративного суду Верховного Суду за 2017 рік.

8. Рішення ЄСПЛ від 28 березня 2006 року у справі «Мельник проти України», заява № 23436/03. URL: https://zakon.rada.gov.ua/laws/show/974_049

9. Макагонюк Ю. Реалізація права на доступ до публічної інформації у сфері екології. Национальный юридический журнал: теория и практика. 2015. Декабрь. С. 88-93 